\title{
A inautenticidade como inflexão no esquema de Schwarz
}

\author{
[ Inauthenticity as an inflection in the Schwarz scheme
}

\author{
Edson Farias ${ }^{\mathrm{I}}$
}

Versão preliminar deste texto foi apresentada no 4I을 Encontro da Anpocs, Caxambu (MG), 23 a 27 de outubro de 20I7. A pesquisa que subsidia este artigo contou com financiamento do CNPq, na modalidade Bolsa de Produtividade em Pesquisa.

RESUMO - Este artigo tem o propósito de ensaiar uma reflexão sobre o lugar-chave ocupado pela inautenticidade como termo de inflexão lógica e sociocultural na formação do regime de autoria artístico-literária no país. Assim, tal como proposto em Ao vencedor as batatas e Um mestre na periferia do capitalismo, examino a contrapartida estabelecida por Schwarz entre a montagem do espaço literário no país e a peculiaridade própria à escrita machadiana, quando esta entrosa cosmopolitismo e localidade no seu discurso. $\mathrm{Na}$ parte final do texto rastreio sugestões a respeito das condições de possibilidade sobre a posição de autoria artística singularizada na figura do mesmo Machado de Assis. P PALAVRAS-CHAVE. Inautenticidade; inflexão lógica e sociocultural; regime de autoria; Machado de Assis; Roberto Schwarz. ABSTRACT - This article has the purpose of rehearsing a reflection on the key place occupied by inauthenticity as a term of logical and sociocultural inflection in the formation of the regime of artistic-literary authorship in the country. Thus, as proposed in "Ao vencedor as batatas" and "Um mestre na periferia do capitalismo", I examine the counterpart established by Schwarz between the assembling of the literary space in the country with the peculiarity proper to Machado's writing, when this cosmopolitanism and locality entwined in his discourse. In the final part of the text, I tracked suggestions about the conditions of possibility on the position of artistic authorship singled out in the figure of the same Machado de Assis. - KEYWORDS - Inauthenticity; logical and sociocultural inflection; authorship regime; Machado de Assis; Roberto Schwarz.

Recebido em 29 de março de 20 I9

Aprovado em I5 de novembro de $20 \mathrm{I9}$

FARIAS, Edson. A inautenticidade como inflexão no esquema de Schwarz. Revista do Instituto de Estudos Brasileiros, Brasil, n. 74, p. 33-60, dez. 2019.

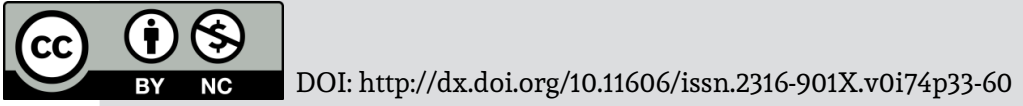

I Universidade de Brasília (UnB, Brasília, DF, Brasil). 
A nota curiosa nesta celebração dos 40 anos da publicação de "As ideias fora do lugar" corresponde à autonomia adquirida por um capítulo em relação ao livro do qual faz parte. No caso, o efeito metonímico obtido pelo capítulo - "As ideias fora do lugar" - o tornou bem mais comentado, mesmo mais conhecido, que Ao vencedor as batatas, livro editado em I977.

O subtítulo desse livro - "forma literária e processo social nos inícios do romance brasileiro" - deixa patente o propósito condutor da argumentação desenvolvida em torno da primeira fase da obra literária de Machado de Assis. Neste artigo, o interesse da argumentação e análise se situa no problema posto pelo subtítulo. Mas, ao que parece, em termos da sua ampla repercussão, a autonomia do capítulo esteve - e é bem provável que ainda esteja - articulada à tensão estrutural estabelecida entre autenticidade e inautenticidade na cultura brasileira (PALTI, I992).

Por certo, o legado da situação de dependência colonial sobre os vários momentos da questão nacional atravessa o argumento posto e desdobrado no capítulo; sobretudo, a mesma chave se atualizou (e atualiza-se) em muitas das expectativas que mobilizam os muitos círculos de recepção compostos em torno do texto. Em especial, pelo tratamento reservado por Roberto Schwarz ao deslocamento na tônica depositada no sistema de ideias liberais à medida que o último deixa a Europa ocidental e aterrissa no Brasil dezenovesco. De núcleo ideológico próprio à afirmação da hegemonia burguesa, em meio à afirmação do Estado-nação, este cada vez mais envolto pela cosmologia do industrialismo, à ambientação do credo liberal na antiga América portuguesa, onde se localiza como uma ideologia de "segundo grau".

Atento a essa "impropriedade" do pensamento brasileiro, no que toca ao contexto do Segundo Reinado, Schwarz sublinha o que ele denomina - mas já em Um mestre na periferia do capitalismo: Machado de Assis (editado em I990) - de "quiproquó ideológico" (SCHWARZ, 20I2a, p. I2O). Fazendo coro com a célebre conclusão de Sérgio Buarque de Holanda - de ser o povo brasileiro "desterrados em nossa terra" (apud SCHWARZ, 20I2b, p. I2) -, o autor retoma a "comédia ideológica” encenada numa sociedade nacional recém-saída da dependência política, sociedade onde os princípios canônicos do Direito dos homens contracenam com uma estrutura social agrário-ruralista cujo protagonismo, em sua estratificação social, cabia ao dueto oligarquia dos grandes proprietários de terras escravocratas e negociantes 
envolvidos com o tráfico humano transatlântico, concentrados no Rio de Janeiro, Salvador e Recife (ALENCASTRO, 2000, p. IO9-II6).

Diante desse quadro, o recurso ao pensamento dialético faculta ao autor requisitar a mútua determinação entre o particular e o universal. Se o esquema consiste no exame de um aspecto atentando à inscrição na totalidade social, Schwarz decanta nas propriedades imanentes aos procedimentos literários machadianos a sincronia com as relações de dominação envolvendo a dimensão "livre" de uma sociedade tendo por dínamo o trabalho escravo. A operação funciona à proporção que o autor avança em analisar como estão transfiguradas as coordenadas, tão duras quanto espessas, da totalização sócio-histórica da escravidão, capazes de preencher possíveis lacunas deixadas como abertura para o exercício de compra e venda da força de trabalho vertida à condição de mercadoria. Desse modo, a arquitetura formal das obras capta, mas recriando enquanto técnica narrativa, o contexto no qual se mantinham cerradas as oportunidades materiais de dignificação individual da pessoa. Portanto, ausentes aqueles componentes elementares ao fetichismo comodificador - tal qual apresentados por Marx no célebre primeiro capítulo de $O$ capital -, os traços cênicos dos trópicos americanos também eram outros, isso ao se tomar por parâmetro tanto a Europa burguesa industrial quanto o realismo elaborado naquele continente. Nesse sentido, a composição literária machadiana pode expor as transformações nas funções das ideias liberais no Brasil, porque ela mesma está atravessada por essas alterações. Mudanças que se deram no Brasil durante o século XIX, período em que se desenvolveu um trançado socioclassista no interior do qual as "multidões de agregados" estavam articuladas às facções capitalistas escravocratas.

A função exercida pela prática do favor incidira, exatamente, no complemento contraditório do descompasso manifesto entre o funcionamento da máquina escravocrata-latifundiária e a esfera cultural comprometida com o universalismo da autonomia individual. Mais do que deixar em xeque o enraizamento da ideologia liberal no país, propõe Schwarz, a escravidão expunha as vicissitudes da aclimatação daquele sistema de ideias na jovem sociedade nacional sul-americana. Em sincronia com o nexo de crenças que o definiu como um instituto fundado sobre o costume do clientelismo, o favor deformara, para atualizar, o credo liberal numa sociedade em que o familismo ocupara (e ocupa) notável primazia nos modos de organização social. Logo, bem ao contrário da experiência europeia, no Brasil teria o liberalismo se aliado ao acento no privilégio, esquivando-se assim de qualquer um dos requisitos do universalismo burguês. Sendo, o último, o arcabouço ideacional à prerrogativa da autonomia e emancipação da pessoa, fundada sobre a antropologia filosófica do ente individual dotado das faculdades cognitivas, de ajuizamento e gosto para lhe conceder autonomia e livre-arbítrio, em coalizão com a "universalidade da lei, a cultura desinteressada, a remuneração objetiva, a ética do trabalho etc." (SCHWARZ, 2000, p. I7). Em sua feição dúbia, aqui adquirida, as premissas liberais pactuariam com "a dependência da pessoa" à "cultura interessada" e ainda seriam cúmplices seja da "exceção à regra”, seja da "remuneração e serviços pessoais".

Segundo ainda o exame de Schwarz, o favor se consolidou como um "mecanismo" pelo qual se reproduziu a estrutura social agrário-escravocrata sobre o esteio do capitalismo, que se tornava industrial, no compasso da sua ampliação sistêmica como 
"economia-mundo" (WALLERSTEIN, 20II, p. I79-358). Com isso, a totalização obtida pelo favor, na condição de prática e instituição com penetração aguda nas implicações entre pobres livres e facções abastadas dominantes - ao focar a peculiaridade brasileira advinda do trânsito entre os regimes colonial e imperial -, singularizaria essa mesma etapa da expansão do capital em escala mundial. Algo assim, na marcha mesma da reorientação socioestrutural, ou seja, da mudança do padrão de estratificação social estamental para aquele vertical-classista, também abarcou o remanejamento pelo qual o Estado colonial fora convertido em Estado-nação, embora, importa sublinhar, o advento e a consolidação desse mesmo arranjo nacional tenham obedecido aos desígnios da subalternidade no cômputo do sistema interestatal. Desse modo, ambos fizeram dueto com a posição subordinada da formação social brasileira na ordem econômica capitalista. No plano próprio às relações econômicas, na divisão internacional do trabalho do então moderno capitalismo industrialista, a jovem sociedade nacional estava fadada à função da agroexportação e, em contrapartida, da importação de bens industriais. Para Schwarz, em se tratando da dimensão das representações e categorias de entendimento, a tradução desse posicionamento periférico do país no concerto capitalista internacional se evidenciava na "caricatura ideológica" intrínseca à maneira como se desenhou a primeira modernidade no país. Nesta, justamente a crença liberal estava atada ao tipo de dominação manifesta no esquema do favor. Afinal, mantidas as mesmas facções de poder econômico-político herdadas do "pacto colonial", as quais foram reiteradas nos trâmites de uma economia-mundo divisada internamente entre centro e periferias, cada vez mais em referência ao domínio técnico-científico, tornara-se imperativo, de um lado, reafirmar o comando das oligarquias rural-escravocratas e dos negociantes escravagistas; do outro, reequacionar o mesmo comando em meio à atmosfera geopolítica e socioeconômica na qual os primados tanto do trabalho livre quanto da autonomia da pessoa já se antecipavam como inquestionáveis axiomas da boa consciência. Afinal, embora subordinada aos desígnios agrário-escravocratas, ainda isolada como um enclave, outra estrutura social se insinuava, tendo por padrão tanto a tônica posta na urbanização acelerada quanto na maior complexificação de uma divisão do trabalho alargada e, cada vez mais, definida pela profissionalização monetária das atividades e também pelo valor conferido à produtividade e ao trabalho metódico-racional.

Por esse viés interpretativo, enfim, Schwarz (20I2c, p. 2I4) retoma as discussões em torno do "desenvolvimento desigual e combinado"; debate que remonta ao modo particular como se tratou do tema da articulação cepalina da questão nacional com a condição de dependência econômica (CARDOSO, I993, p. 27-80) e política das sociedades latino-americanas, em particular o Brasil, na sistemática capitalista, durante as reuniões do círculo uspiano de leitura de $O$ capital, na passagem da década de I950 para a de I960 (RODRIGUES, 20II; BIANCHI, 20Io, p. 97-20I). No prefácio do já aludido Um mestre na periferia do capitalismo: Machado de Assis, ele mesmo assinala que o retorno àquelas discussões fora conduzido pela atenção à posição colonial brasileira no sistema intelectual e nos circuitos internacionais da circulação de ideias.

Assinado por Bernardo Ricupero, publicado em 2008, ano em que se celebraram os 30 anos do famoso capítulo, o artigo "Da formação à forma. Ainda as 'ideias fora do lugar” deixa por saldo uma razoável escuta da recepção do ensaio de Schwarz. Se 
o texto envereda pelo descompasso entre as ideias liberais e o solo escravocrata, sem perder de vista a mediação exercida pelo favor, interessa a Ricupero expor que, para além de expressar um fato - a "inadequação de certas referências intelectuais a um dado contexto social" -, o famoso ensaio de Schwarz indexa o processo formativo da literatura brasileira, que alcançaria maturidade formal no romance machadiano da última fase do literato (RICUPERO, 2008, p. 64). Sob esse ponto de vista, o trajeto percorrido tanto em Ao vencedor as batatas quanto em Um mestre na periferia do capitalismo relata o movimento pelo qual a pena literária machadiana retém e representa a realidade sócio-histórica, mas igualmente a torna matéria configurada por intermédio da composição dramático-artística, portanto, obediente ao conjunto de convenções informante do fazer, logo, próprio ao artefato mimético literário, na sua dupla condição de bem simbólico e estágio de simbolização.

Quando anota a centralidade ocupada pelo movimento no qual se fazem triangularmente recíprocos o processo sócio-histórico, a formação literária e a forma estética no projeto intelectual no qual se inscreve "As ideias fora do lugar", Ricupero aborda o que entendo ser decisivo no ensaio de Schwarz: delinear a construção metodológica apta a expor a dialética entre romance e sociedade escravagista com a sua cultura do favor. Com isso, são tecidos os nexos lógicos, da forma e dos teores, no que toca à continuidade do traço ambíguo em que se precipitam mútuos: "alheio" e "próprio", "dentro" e "fora" (SCHWARZ, 2000, p. 3I). À inflexão da inautenticidade corresponde, portanto, o ponto em que se modulam, em reciprocidade, esses topos; ao se dobrarem sobre o seu próprio eixo, eles se fazem afins na medida em que se opõem. Incorporada ao pensamento social, partir do interesse em torno do genuíno por parte do braço alemão da matriz romântica, mediante a perspectiva fenomenológica existencialista, com sua aplicação ao tema da essência (BADIOU, 2005; EWALD, 2008), a ideia de autenticidade remonta aos requisitos de unicidade e singularidade do ser, quer dizer, está comprometida com a permanência da não contradição na definição de algo. Desprovida do fundamento ontológico da integridade, na condição de elemento antitético, a inautenticidade instaura, na ordem do ser, a inapropriação. Em termos de validez, ela se desdobra na ilegitimidade, no espúrio, no falso (GONÇALVES JR., 2005). Eu entendo que, no esquema analítico de Schwarz, a semântica da inautenticidade é acatada no seu arsenal de categorias com fins de objetivação sociológica da correlação sócio-histórica entre literatura e estrutura social. Embora o desprenda da tônica existencialista, ele não despreza o aspecto fenomenológico, afinal se ocupa de uma forma de consciência pela qual se entrosam as dimensões pessoais e coletivas. Desse modo, o inautêntico diz respeito ao fator de mediação entre os muitos planos entretidos no problema examinado. Diria 
ser o termo com o qual se expõe determinado "temperamento"2. Ou seja, o padrão emocional e cognitivo que constitui a dimensão cultural de significação daquele estágio sócio-histórico intrínseco às consequências da circulação internacional das ideias liberais no contexto escravocrata brasileiro e, ainda, repercute na posição de autoria que traduz como mimese literária tal mútua modulação pela qual se relativiza a autorreferência do local e do universal-histórico.

No trecho que encerra o ensaio de abertura de Ao vencedor as batatas, o autor contorna as feições do método adotado na abordagem da obra machadiana. No núcleo do seu esquema analítico-interpretativo, tal qual assinalado acima, a mediação da forma literária tem por matéria e objeto o favor enquanto mediador social ("forma social”, ideológica), isso, na estrutura escravocrata brasileira, entendendo esta última no escopo da universalização histórica do capitalismo. Porém, no reverso da medalha, perscrutando a determinação macrossociológica nas texturas da sua localização nas condições da produção literária de uma específica sociedade periférica. Tomo a liberdade de citar Schwarz:

[...] ao contrário do que geralmente se pensa, a matéria do artista se mostra assim não ser informe: é historicamente formada, e registra de algum modo o processo social ao qual deve a sua existência. Ao formá-la, por sua vez, o escritor sobrepõe uma forma a outra forma, e é da felicidade desta operação, desta relação com a matéria pré-formada - em que imprevisível dormita a História - que vão depender profundidade, força, complexidade dos resultados. São relações que nada têm de automático, e veremos no detalhe quanto custou, entre nós, acertá-las para o romance. E vê-se, variando-se ainda uma vez mais o mesmo tema, que embora lidando com o modesto tic-tac de nosso dia a dia, e sentado à escrivaninha num ponto qualquer do Brasil, o nosso romancista sempre teve como matéria, que ordena como pode, questões da história mundial; e que não as trata, se as trata diretamente. (SCHWARZ, 2000, p. 3I).

Neste artigo, o retorno à discussão acerca do método que compõe Ao vencedor as batatas e Um mestre na periferia do capitalismo tem o propósito de ensaiar uma reflexão sobre o lugar-chave ocupado pela inautenticidade como termo de inflexão lógica e sociocultural na formação do regime de autoria artístico-literária no país. Assim, à luz dos argumentos desenvolvidos em ambos os livros, examino a contrapartida estabelecida por Schwarz entre a montagem do espaço literário no país e a peculiaridade própria à escrita machadiana quando esta entrosa e, ao mesmo tempo, deixa em suspenso o que seriam as propriedades essenciais do cosmopolitismo

2 Tomo de empréstimo a Gregory Bateson (2008) a categoria de temperamento cultural, porque interessa sublinhar o plano da estrutura cultural no tocante às propriedades de comportamentos generalizados. De acordo com o autor, o temperamento consiste no "tom", isto é, no "fundo emocional" de uma cultura, e é revelador do ethos como fator de intercessão entre instância prática e sistema de conhecimento numa sociedade. Corresponde, assim, ao "sistema culturalmente padronizado de organização dos instintos e das emoções dos indivíduos" (BATESON, 2008, p. I7I). Manifesto na empiria dos comportamentos, para o antropólogo, pelo temperamento se explica a articulação entre os instrumentos classificatórios que presidem a realização de inteligibilidades (eidos), a coerência societária e os vínculos interpessoais. 
(alheio) e da localidade (própria, autóctone) no seu discurso. Com o respaldo oferecido por esse traço ambíguo, na parte final do texto esboço sugestões a respeito das condições de possibilidade sobre a posição de autoria artística singularizada na figura do mesmo Machado de Assis.

\section{O DESENHO DO MÉTODO NOS RASTROS DA COMPULSÃO AMBÍGUA}

Leopoldo Waizbort (2007) rastreia as referências dispostas ao longo de Ao Vencedor as batatas. Com isso ele reconstitui os pontos da interlocução teórica que, num mesmo diapasão, se entrelaçam na construção do problema estético-literário e sociológico e também informam saídas analíticas que engendram o material sistematizado na pesquisa e suscitam as interpretações propostas no livro Ao vencedor as batatas. O fino esforço filológico realizado por Waizbort dispensa a tarefa de reconstruir o tramado conceitual implicado na abordagem de Schwarz. Retenho, porém, um aspecto. De acordo com Waizbort, a problemática de Ao vencedor as batatas dialoga com o objetivo de Erik Auerbach (I97I) - em Mimesis ${ }^{3}$ - de abrir o pensamento para "outras configurações 'realistas' particulares na perspectiva geral que o livro arma" (Waizbort, 2007, p. 23). No que se refere ao texto de Schwarz, a finalidade estaria em elucidar o realismo próprio à letra de Machado de Assis. "O que equivale indagar como a literatura de Machado de Assis expõe a realidade, se e como a 'retrata', 'espelha', 'ilumina', 'apresenta', qual a relação que estabelece entre 'realidade' e 'obra literária”" (WAIZBORT, 2007, p. I3).

A escalada das indagações levantadas acima parece ter motivado Schwarz ainda seguindo os rastros de Waizbort - a evocar e, na mesma iniciativa, reciclar as formulações lukacsianas sobre o romance e a vida burguesa, mas levando em

3 O empenho de aliar o cuidado filológico à prioridade devotada pela sociologia às "forças históricas" determinantes da objetivação espaçotemporal das categorias e, com isso, levando em conta as maneiras como forma artística e forma social se atravessam, responde à aposta de Erik Auerbach no método histórico-formal, o qual é aplicado mediante o esforço comparativo em Mimesi. Algo assim conduz Auerbach na reflexão acerca das reciprocidades estabelecidas entre a forma literária e as nuances nas temporalidades relativas aos processos histórico-sociais. Movido pelo debate nucleado pelo realismo, o autor evoca o problema a respeito da transfiguração do processo social na composição literária. Na medida mesma que, para o autor, o realismo consiste numa categoria sobre as representações situadas espaçotemporalmente das ambientações humanas, para ele, a continuidade trans-histórica da categoria ocorre à luz dos teores adquiridos ao sabor das próprias transições e acomodamentos no espaço e no tempo das regras de exposição realizada pela escritura literária. Em lugar de recorrer a fórmulas abstratas, a seu ver, cabe ao analista imergir nas figurações próprias às específicas situações histórico-sociais referentes à concatenação de elementos estético-estilísticos com os quais uma obra literária expõe uma sociedade, de acordo com as suas coordenadas internas (WAIZBORT, 2004, p. 6I-9I). 
consideração o desenvolvimento capitalista 4 . Igualmente o teria impelido a cotejar as contribuições sobre a forma estética em Adorno, para aquilatar o "rigor construtivo" da mimese literária machadiana, por concluir sobre a "justeza" da obra no momento em que sintoniza a técnica narrativa tanto com a vida ideológica como também com a estrutura social vigente no país durante o Império (SCHWARZ, 2OI2a, p. 57)5.

Sem recusar a relevância dessas referências no delineamento da abordagem de Schwarz, em Ao vencedor as batatas chamo a atenção para a sintonia metodológica com o esquema de "Dialética da malandragem" (CANDIDO, I970), denunciada pelo próprio autor. A seu ver, no movimento de elucidação do realismo machadiano, a recuperação do esquema de Antonio Candido deixa por saldo uma abordagem apta ao exame da economia emocional das facções abastadas dominantes brasileiras no século XIX. Avançar no esboço dessa reflexão requer ser mais paciente no exame do esquema metodológico adotado por Schwarz.

Publicado após a primeira obra sobre Machado de Assis, no livro Que horas são?, com o ensaio "Pressupostos, salvo engano, de 'Dialética da malandragem"” (SCHWARZ, I987), o autor excursiona pelo texto de Antonio Candido (I970),

4 Motivado pelo exercício hegeliano de expor a evolução histórica do espírito, quando se impõe a tarefa de historicizar as categorias estéticas, com a excursão realizada em $A$ teoria do romance, Lukács (2000, p. г3) busca empreender uma "dialética universal de gêneros fundada historicamente". Para isso, persegue a permanência da forma estética no compasso das mudanças sócio-históricas, em meio à sucessão entre os gêneros literários no escopo da civilização ocidental. A tensão primordial que se estabelece é aquela entre essências/formas e vida/existência. Desse modo, o pensador húngaro detém-se na longa passagem da forma trágica, que se manifesta tanto na epopeia grega quanto no drama shakespeariano, desaguando no advento do romance. Alterna-se, nessa tocada, a presença do sentido na condução da vida: na antiguidade clássica, permanece imanente à vida; entre os modernos, torna-se intrínseco a uma esfera transcendente à existência. Mais tarde, atento às propriedades do gênero romanesco, Lukács se debruça ante o problema da mediação literária, interrogando o "realismo". Se a discussão em pauta tem por objeto o "reflexo da realidade", para ele, não se trata do mero espelhamento. Afinal, afirma, a forma literária consiste em leis universais e sistemáticas de apreensão e exposição dos episódios das coisas da vida e do mundo. Caberia à "grande arte", conclui, representar momentos típicos da evolução histórica da humanidade, assim, acionando no leitor a autoconsciência da sua participação nessa mesma dinâmica (LUKÁCS, 20I0, I49-I86).

5 A contramão da ênfase kantiana na unicidade da obra, por conta da exigência de coerência entre as propriedades e momentos do artefato, para daí fazer derivar a divisão irredutível da arte em relação à multiplicidade do empírico, Adorno (I992, p. 68-7I) insiste que, na obra de arte, numa negativação recíproca, tensionam-se o imperativo da forma lógica e os momentos divergentes dos tantos particulares inscritos em sua materialidade. A seu ver, a unidade estética vem no caudal da totalização desses particulares, porque se os determina enquanto causalidade, concatenando-os, igualmente ela é determinada por essa concatenação. Para o filósofo, a arte consiste numa modalidade de conhecimento cujo esquema cognitivo recusa a instrumentalidade que impõe a identidade do sujeito e do objeto, em obediência à eliminação da heterogeneidade do empírico, para assegurar a funcionalidade dos materiais aos propósitos da razão subjetiva. Portanto, animada pela inutilidade, já que é "cega" ao objeto sobre o qual operaria, a arte contempla um ato de conhecer com mútuas implicações entre forças que não se anulam entre si e, ao mesmo tempo, não são dissolvidas, enquanto alteridades, pela atividade conceitual do espírito de esclarecer e do seu autoesclarecimento. 
enfocando estar a novidade da obra em se constituir no "primeiro estudo literário propriamente dialético". De acordo ainda com Schwarz, enfim, fora estabelecida a correlação da análise formal com a localização sociológica no esforço de, a um só tempo, "identificar, denominar e colocar em análise" o que chama de "linha de força da malandragem”. Esta última atravessaria escritos e gerações desde a Colônia, a exemplo de manifestações incorporadas ao personagem folclórico Pedro Malazarte (de Gregório de Matos), igualmente presentes no humorismo popular, na "imprensa cômica e satírica da Regência, num veio de nossa literatura culta do século XIX, e culmina no século XX, com Macunaíma e Serafim Ponte-Grande, onde é estilizada e elevada a símbolo" (SCHWARZ, I987, p. I30).

No andamento do ensaio, Schwarz destaca como, durante a análise de Memórias de um sargento de milícias, romance de Manuel Antônio de Almeida, o protagonismo exercido por um "herói malandro", segundo as convenções de um romance representativo, num realismo original, compõe a "intuição e figuração de uma dinâmica histórica profunda” (SCHWARZ, I987, p. I3I). A dialética da malandragem corresponde, portanto, à transfiguração discursiva daquele ritmo da sociedade brasileira, na primeira metade do século XIX, em que se aproximam e fustigam ordem e desordem. A proeza de Antonio Candido estaria, para Schwarz, em reconhecer nessa dialética um "princípio de generalização que organiza em profundidade tanto os dados da realidade quanto os da ficção (sejam ou não documentários), dando-lhes inteligibilidade" (SCHWARZ, I987, p. I33).

Assim, a junção de romance e sociedade se faz através da forma. Esta é entendida como um princípio mediador que organiza em profundidade os dados da ficção e do real, sendo parte dos dois planos. Sem descartar o aspecto inventivo, que existe, há aqui uma presença da realidade em sentido forte, muito mais estrita do que as teorias literárias costumam sugerir. Noutras palavras, antes de intuída e objetivada pelo romancista, a forma que o crítico estuda foi produzida pelo processo social, mesmo que ninguém saiba dela. Trata-se de uma teoria enfática do realismo literário e da realidade social enquanto formada. Nesta concepção, a forma dominante do romance comporta, entre outros elementos, a incorporação de uma forma da vida real, que será acionada no campo da imaginação. Por outro lado, não se trata de um realismo espelhista, pois uma forma não é toda a realidade, além do que ela pode se combinar com elementos historicamente incaracterísticos (o aspecto folclórico das Memórias, que leva o romance para o lado fabuloso). (SCHWARZ, I987, p. I4I).

A identificação da qualidade artística do romance Memórias de um sargento de milícias, a qual o apreende como um todo em movimento, deixa por lição metodológica a ênfase na composição da obra. Contudo, algo assim não significaria apartar o estético do social, porque o efeito mimético do artefato literário estaria na "imitação de uma estrutura histórica por uma estrutura literária” (SCHWARZ, I987, p. I35). No momento em que reconhece a realidade como "formada", o autor aponta à dimensão significante que, na sua permanência indiscutida, aproxima seletivamente aspectos díspares do real histórico, amalgamando-os como peças de uma mesma consciência tácita. No funcionamento do esquema analítico aplicado a Memórias de um sargento 
de milícias, encontrar-se-ia a versão literária de um horizonte histórico das classes populares, porém este não consiste na empiricidade crua de significações, porque nela já opera uma forma que lhe confere inteligibilidade. Com isso, por apropriar-se da dialética da ordem e da desordem do mundo popular no desdobramento da dinâmica dramática do texto, a tradução realizada pela composição literária de Manuel Antônio de Almeida penetraria a intimidade dessa realidade.

Entende Schwarz que o resultado obtido pela análise empreendida por Candido teria sintetizado as linhas particularistas e universalistas na formação da literatura brasileira. Enfim, para o autor, o nexo lógico do argumento defendido em "Dialética da malandragem" ratifica a originalidade do nacional, ou seja, a particularidade (a exemplo do fabuloso "mundo sem culpa" do popular), mas o faz no movimento de reconhecê-lo como ingrediente da cena de processos contemporâneos relacionados à universalização histórica do capital. Processo histórico de unificação dos mercados com penetrantes efeitos no desmonte do ensimesmamento das culturas, vicejando um comum irredutível aos nichos nacionais. Justamente a essa altura da explanação, na nota de rodapé número 4, Schwarz aproxima a iniciativa de Candido à postura de Machado de Assis de tornar inteligível, em lugar de instaurar (como teriam pretendido as vozes do romantismo), o sentimento de identidade patriótico, imaginativamente elastecendo o campo das suas possibilidades temáticas de manifestações e, no contraverso, o decompondo na análise. Conclui Schwarz (I987, p. I37): Machado ostenta o título de ser o "primeiro romancista não provinciano, isto é, universal e adulto" da literatura brasileira. Ele o é em razão do exercício literário realista que se consolida por investigar, tornando-a matéria-prima, a forma de mediação da inautenticidade que, simultaneamente e de maneira mútua, ratifica e coloca em xeque tanto a naturalidade do próprio quanto a necessidade universal do alienígena.

O ensaio em que o autor comenta "Dialética da malandragem" é editado em I987, portanto, dez anos após o lançamento de Ao vencedor as batatas, mas três anos antes da primeira edição de Um mestre na periferia do capitalismo. Considerando essa localização, não me parece arbitrário supor que o ensaio faz a inflexão do percurso construído pelo autor, principalmente no que toca ao estudo e à pesquisa da forma romanesca machadiana. A escuta atenta dos pressupostos do trabalho de Antonio Candido também lhe oportunizou a reflexão acerca dos princípios que o conduzem à análise e interpretação realizada nos dois livros sobre Machado de Assis. O desenho do método de Schwarz dialoga com o repertório de ferramentas de Candido, porque lhe permite apreender a forma como se processa a transfiguração estética de um processo sócio-histórico - este mesmo possuidor de um padrão no seu desdobramento ${ }^{6}$. Igualmente, creio verossímil propor que o ensaio "Dialética da malandragem” fornece a Schwarz componentes teóricos acionados na elucidação das problemáticas intrínsecas a cada um dos dois livros, problemáticas essas que

6 No ensaio bibliográfico “Ideias, intelectuais, textos e contextos: novamente a sociologia da cultura”, João Marcelo Ehlet Maia (2005, p. 63) também identifica a proximidade de método entre Candido e Schwarz, já que ambos se propuseram à análise literária examinando a correlação dialética entre forma artística e processo social. Observa que os dois intérpretes depositaram tônica na mediação exercida pela forma no tocante à relação entre a existência concreta do autor literário e o contexto no qual se inseria. 
se interligam na medida em que o tema da mediação do favor (em Ao vencedor as batatas) contracena com a questão em torno dos traços autoritários e perversos da "volubilidade" do narrador-autor (em Um mestre na periferia do capitalismo), devido à igual inflexão da inautenticidade. Com isso, sendo cada um desses aspectos os respectivos princípios informantes das fases específicas na carreira autoral machadiana, Schwarz extrai da análise de Candido a "relação de mimese" com a peculiaridade brasileira cuja silhueta ambígua faz coadunar, segundo ele, fórmulas de tolerância, desigualdade e acomodação7.

Nesse debate em que o foco se dirige ao problema dos modos de subjetivação (enfim, os $e^{\text {thos }}{ }^{8}$ ), compartilhados entre membros de específicos segmentos de classe social, a interferência de Schwarz introduz como dado novo aquilo antes denominado de “quiproquó ideológico". Quer dizer, insere nessa pauta de problematizações o efeito gerado pela circulação internacional de ideias, sabendo-se que essa circulação vem no caudal da expansão capitalista, a qual, por sua vez, faz dueto com a montagem

7 Nos dois autores se enfoca a peculiaridade do padrão comportamental nas linhas de conduta das extrações das classes dominantes e dos segmentos não escravizados pobres, mas ao longo da formação do Estado-nação brasileiro, em seu período dezenovesco. Creio necessária tal observação com vista a separar o que um e outro intérprete formulam do olhar lançado pelo antropólogo Roberto DaMatta (I997, p. I5-42) sobre o que denomina de o "dilema brasileiro". Ainda que também persevere um igual esforço de totalização, para o antropólogo tal dilema diz respeito ao problema das "ideologias abrangentes" dispostas à contrapartida do perfil de uma sociedade periférica no concerto do capitalismo mundial; sociedade na qual o plano dos valores seria o palco do choque da racionalidade burguesa com um conjunto de valorações enraizadas na tradição, herdadas do passado colonial luso-católico e escravocrata. O peso do modelo durkheimiano na letra do antropólogo se revela à medida que nos inteiramos da antecedência gozada por uma espécie de moralidade-nação que, na sua condição de idealidade, se faria intransigente diante das incongruências inerentes ao cotidiano imolado pelas contradições várias, entre classes sociais, entre dominantes e dominados. Por exemplo, quando trata do carnaval brasileiro, o que estaria em pauta na análise e interpretação damattiana seria a propagação, por intermédio do ritual, de um mesmo conjunto de representações coletivas capacitadas a gerar uma solidariedade social por entre e por sobre o relevo acidentado das estratificações entre os grupos, no seio de uma estruturação devotada a reiterar seu apreço à desigualdade e à hierarquia. A situação festiva, ainda que efêmera, e à sombra das tensões que a compõem, fomentaria um concerto equilibrado ultrapassando dualidades e divisões; estaríamos diante do povo-nação na sua feição de unidade de parentesco (FARIAS, 20I2, p. 60).

8 Faço uso do termo ethos calcado na maneira como Michel Foucault o incorpora no exame do amplo corpus documental do que passou a denominar de "história das práticas de subjetividade", na virada das décadas de I970 e I980, nos cursos ministrados no Colégio de France. Atento ao tema helenístico do cuidado de si (epiméleia heautoú), ele acompanha o percurso dessa fórmula que ultrapassa os muros filosóficos e se acomoda como um ethos e padrão cultural entre facções dos segmentos dominantes na antiguidade greco-românica, vindo a declinar já no avanço da cristandade pelo ocidente europeu. A noção de cuidado de si se estendia para bem além de uma atitude voltada a si mesmo, pois se realiza em série de práticas que eram majoritariamente "exercícios, cujo destino (na história da cultura, da filosofia, da moral, da espiritualidade ocidental) será bem longo. São, por exemplo, as técnicas de meditação, as de memorização do passado, as de exame de consciência, as de verificação das representações na medida em que elas se apresentam ao espírito, etc." (FOUCAULT, 2004, p. I5). 
do arranjo interestatal. Possível com a implantação e o acirramento das circulações interatlânticas (ABREU, 20I6), mas mediante os mais diversos suportes às letras (livros, imprensa etc.), a transposição dos ideários liberais não deixou incólumes as paisagens e os cenários brasileiros, tampouco os padrões de subjetividade. Esse é um problema já focalizado por Gilberto Freyre (2000, p. 32-3830) em Sobrados e mucambos, no instante em que a formação do patriarcado urbano contracena, na sua análise, com a estilização e pacificação dos comportamentos das oligarquias. A seu ver, ambas as tendências estiveram manifestas no que chama de "artificialização" das atitudes em público. Se esteve relacionada às consequências urbanizadoras e industrialistas deflagradas no compasso da expansão cafeeira no centro-sul do país, com manifestações nos planos arquitetônicos, da higiene pública e doméstica, do consumo de bens, das modalidades de diversão, decoração dos lares e embelezamentos citadinos, entre outros ambientes, no que concerne às moralidades e aos andamentos comportamentais, a artificialização se deu em relação a quê?

Nos rastros da interpretação freyriana presente em Casa-grande e senzala (FREYRE, I987, p. 3I6-32I), mas já de posse seletiva do esquema analítico eliasiano em torno da psicogênese9 (ELIAS, I990), Ricardo Benzaquen de Araújo (I994) observa que o liame entre "sadismo" (dos senhores) e "masoquismo" (dos escravos) definia um padrão de relacionamento e dominação próprio aos domínios das propriedades rurais, em que prevalecia o regime escravocrata de trabalho. Para ele, esse padrão tinha por base a educação - se a entendemos como um processo de modalização das pulsões - cujo resultado se apresentava no delineamento de um eu movido pelo "gosto

9 A certa altura da argumentação desenvolvida em A sociedade dos indivíduos, Elias (I994) esmiúça a teoria da individualização correlata ao seu modelo de dinâmica sociocivilizatória, sobretudo elucidativa do que entende por estrutura psíquica ou economia emocional - objeto por excelência do equipamento da psicogênese como pesquisa da formação de padrões sócio-históricos de autorregulação humana. A individualização consiste no processo de diferenciação das funções psíquicas, isto é, funções de autorregulação em relação a outras pessoas, outros seres vivos e também às coisas: “O que chamamos 'instintos' ou 'inconsciente' constitui também uma forma específica de autorregulação em relação a outras pessoas e coisas, apesar de ser uma forma que, dada a nítida diferenciação das funções psíquicas, já não controla diretamente o comportamento, mas o faz em vários desvios" (ELIAS, I994, p. 37). Resgatando a antiga concepção grega de "alma” (psique), Elias a define como a estrutura formada pelo tramado de relações psíquicas, compondo valências mútuas. Estrutura caracterizada pela maleabilidade própria do elemento instintual humano, ou seja, presença tênue de predeterminação hereditária que, por sua vez, pode supor a moldagem sociogenética das funções psíquicas - em outras palavras, a tendência no complexo humano do controle psíquico sobre o organismo. Isso porque, entende o autor, essa transitividade em relação ao fator hereditário atrai o constrangimento da rede social. Conclui, então, estarem em mútua complementaridade as estruturas da psique humana, as estruturas da sociedade humana e as estruturas da história humana: "Uma vez que o controle relacional relativamente indiferenciado da criança recém-nascida só se torna diferenciado e regulado por meios humanos na relação com os outros seres humanos, o que emerge como 'alma' do indivíduo adulto não é estranho à sociedade e associal em si mesmo, mas algo que, já em sua própria base, constitui função da unidade relacional de um poder superior a que chamamos 'sociedade'. Toda maneira como o indivíduo se vê e se conduz em suas relações com os outros depende da estrutura da associação ou das associações a respeito das quais ele aprende a dizer 'nós"' (ELIAS, I994, p. 37). 
de mando violento e perverso" (FREYRE apud ARAÚJO, I994, p. 50). Quadro posto no microcosmo em que a desigualdade descomunal entre os abastados terratenentes e os demais, sobretudo os escravizados, amparava-se num quadro de valores hegemônicos na vida colonial socioestruturalmente ditada pela economia agroexportadora, tocada pelos latifundiários escravocratas. Nesse mesmo cenário social, a tônica estaria depositada no excesso como índice valorativo de distinção humana e, logo, centro da eleição do que merecia dignidade e reverência. $\mathrm{O}$ ato excessivo revelado, seja no recurso à força bruta, seja nos prazeres obtidos mediante o coito feito só em favor daquele ocupante da posição de senhor. No emprego do conceito de hybris (no sentido de deformação e relacionamento), Benzaquen de Araújo (I994, p. 70) concebe aquele corpo senhorial "adulterado e amolecido pelo ócio assegurado pela escravidão".

O deslocamento para a cidade teria estilizado, sem esterilizar, tal padrão de conduta movida pelo excesso. Para o mesmo Gilberto Freyre (2000, p. 600-659), o amortecimento esteve relacionado à intensificação do trânsito entre o Brasil e a Europa burguesa industrializada. A gradual ambientação dos segmentos patriarcais nos cenários urbanos lhes fomentou, portanto, uma transição comportamental. Isto é, da pouca parcimônia nas exposições de sentimentos contrastantes entre si em círculos familiares e paroquiais, ganharia relevo certa psicologização que se manifestara nos adiamentos daquelas mesmas exposições públicas das emoções. Estas passam, desde então, a estar sempre mais reguladas pela inserção de instâncias que requisitam a teatralização dos atos no convívio público (em espaços religiosos ou mundanos) com faç̧ões diferentes, ainda que das mesmas classes, e dessa maneira requerem o refinamento dos gestos no compasso do aprofundamento dos mecanismos de controle subjetivo das atitudes. Percepção ratificada por Schwarz.

Este último, porém, sonda a contraditória estilização da hybris na formalização estética do processo sócio-histórico em que a "universalização psicológica da escravidão" comparticipa da composição romanesca na obra de Machado de Assis, a qual se deu nas condições citadinas de um Rio de Janeiro que acolhe os círculos familiares do patriarcado sempre mais atravessados pelos ditames da vida burguesa industrial da Europa norte-ocidental. Sendo os mesmos ditames reciclados pelas coordenadas dos modos gerados nos trópicos coloniais luso-brasileiros.

Em Ao vencedor as batatas, restringindo a análise aos romances da juventude machadiana (A mão e a luva, Helena e Iaiá Garcia), o autor foca-se na situação dos agregados, aqueles cuja subordinação à lógica do favor os priva da prerrogativa liberal da autonomia pessoal. Dispondo-os comparativamente, Schwarz anota a reorganização da "matéria literária" ocorrida no trânsito entre José de Alencar e Machado de Assis. No primeiro, a tônica crítica romântica se mantinha em consonância com a matriz do individualismo burguês europeu, para o qual a intransigência diante da opressão da "sociedade" respondia aos anseios de plena transcendência do indivíduo. No romance Senhora, de Alencar, por exemplo, destacar-se-ia o cálculo instrumental da protagonista cuja ascendência socioeconômica lhe angariou recursos para efetivar os seus anseios de justiça e dignidade, os quais lhe foram negados quando compunha o espaço social dos pobres. Entretanto, a mesma coerência ideológica interna ao modelo de um realismo europeu resultava em déficit da forma romanesca alencariana com a cosmologia brasileira 
porque, argumenta Schwarz, suplantava a prioridade da família (e dos costumes) por uma inverossímil primazia da impessoalidade do meio de pagamento universal. Por sua vez, para manter-se em sintonia com o primado realista, embora comprometesse a fidelidade do gênero romance com o ideário individualista, a pena machadiana acolheria melhor a empiria brasileira no princípio formal que rege sua prática romanesca. Observa Schwarz que, tratando do mesmo tema da ascensão social, Machado de Assis penetra com maior sutileza no âmbito da intimidade e, dessa maneira, revela como a universalização da troca mercantil estava limitada, no Brasil, pela antecedência do respeito ao decoro, logo, reverência aos costumes relativos ao familismo estamental colonial brasileiro. Conformismo e acomodação impunham limites precisos à prerrogativa do que seria uma degradação total promovida pela unidade do dinheiro com a competição animada pela vontade individual.

A diferença ressalta bem na maneira de encarar a ascensão social: num caso aponta-se para o preço desta, ainda quando bem-sucedida, pois o carreirista transforma a si e aos outros em degraus; no outro estudam-se as condições em que ela, em si mesma desejável, se completa com dignidade, para além do próprio carreirista, mas também das boas famílias, que se beneficiam de seu talento, e finalmente de nossa sociedade brasileira, que precisa aparar as suas irregularidades e aproveitar o elemento humano de que dispõe. Em lugar da oposição absoluta de indivíduo e sociedade, da instrumentalização geral e do correspondente radicalismo crítico, estão a comunidade de costumes, de interesses e crenças, o desejo de melhorar e o arranjo. Favor, cooptação, sutilezas da conformidade e da obediência substituem, no miolo do romance, o antagonismo próprio à ideologia do individualismo liberal. (SCHWARZ, 2000, p. 93-94).

Seria equivocado derivar da interpretação de Schwarz o reconhecimento do mero cinismo por parte de Machado de Assis. Em especial quando analisa A mão e a luva, o autor sublinha como a composição literária machadiana guarda, no compasso em que revela, a ambiguidade dos dependentes quanto ao cosmo em que se inscrevem. Estão frustrados quanto à pretensão da individualidade afirmada como direito, em razão da subordinação à arbitrariedade familiar-estamental. Porém, na mesma compulsão dual, a frustração assinala a insatisfação com a ordem patriarcal. A um só tempo, eles ficam aquém de encenarem os valores da ordem burguesa e, no mesmo diapasão, mantêm em silêncio tenso a desaprovação moral diante dos excessos dos dominantes:

Um impasse delicado, como se vê, em que se equilibram a crítica e a posição defensiva, e cuja exigência estética é de descaracterização: reduzida a estado tácito, não sendo sequer a aspiração dos personagens, a expansão não tolhida das faculdades individuais está presente apesar de tudo, enquanto medida da renúncia, e faz parte do horizonte do livro. Em suma, os conflitos não se declaram e não se suprimem, donde o clima geral de constrangimentos, que expressa as duas lealdades de Iaiá Garcia às esferas paternalistas e do individualismo burguês e o sacrifício que fazem uma à outra. (SCHWARZ, 2000, p. 2IO). 
Já em Um mestre na periferia do capitalismo, o polo aglutinador dramático está no representante das facções de classe dominante do Segundo Reinado brasileiro - o personagem principal do romance Memórias póstumas de Brás Cubas. Sobressai no protagonista dessa obra, justamente, uma vez mais, a ambiguidade dos gestos em que a visão ilustrado-romântica liberal faz par com a volubilidade engajada na atitude caprichosa de um narrador dado a toda sorte de excessos. Como explica Schwarz: "a volubilidade de Brás Cubas é um mecanismo narrativo em que está implicada uma problemática nacional”.

No capítulo "Ricos entre si" (SCHWARZ, 20I2a, p. 74-95), o autor se volta ao tecido narrativo em que é encenado o convívio dos abastados no curso da trama machadiana. Observa Schwarz o uso crítico e reflexivo, a um só tempo preciso e irônico, do vocabulário do naturalismo, por Machado de Assis, quando convoca os tópicos da raça, mediante a figura da hereditariedade, e do meio - no apelo ao clima, isso em razão da discussão acerca das causas subjacentes à "deseducação de Brás". Na contramão da tendência eclética dos círculos intelectuais do Império, ávidos em recrutar teorias europeias para explicar os fenômenos brasileiros, Machado descreditaria as determinações naturais no excurso pelo qual expõe tipos humanos que, conectados, delineiam um ambiente social, um “meio". Porém, tratar-se-ia de um meio cultural a ser explorado cientificamente levando em conta a segunda natureza humana fomentada pela persistência de instituições advindas do período colonial. Contornando a anedota moral, a "deseducação de Brás" seria explicada pela hereditariedade portada pelo personagem, a qual contracena com encadeamentos geracionais que lastreiam um padrão psíquico. Ao modo de uma psicogênese da economia emocional do patriarcado estendida do ambiente rural ao urbano, o literato desvela o entretido de valores enaltecendo a virilidade no tocante ao exibicionismo e desempenho sexual, mas também os desequilíbrios nas relações sociais de gênero, revelado no acanhamento do polo feminino, e o status depositado no emprego da violência, em particular com os subalternos escravizados, que informaria o que, a princípio, corresponderia apenas ao traçado singular do protagonista das Memórias póstumas:

Como se explica o caráter de Brás Cubas? A resposta está na infância da personagem, no meio doméstico, no temperamento herdado e na educação recebida. O pai, impermeável às exigências da moral ou razão, mira-se nas tropelias do menino com fatuidade e gozo irrestritos. "[...] e se às vezes me repreendia, à vista da gente, fazia-o por simples formalidade: em particular dava-me beijos". A mãe "era uma senhora fraca, de pouco cérebro e muito coração, assaz crédula, sinceramente piedosa - caseira apesar de bonita, e modesta apesar de abastada; temente às trovoadas e ao marido”. O tio João destaca-se por faltar à decência em companhia das escravas e mulheres fáceis, ao passo que o outro tio, o cônego Ildefonso, sendo irrepreensível quanto à pureza, vive mais para as cerimônias de culto que para o espírito da religião. Por seu lado, a escravaria oferece campo propício às brutalidades e caprichos de Brasinho, que aliás atingem também as visitas da casa, cuja reação complacente possivelmente se deva à proeminência da família Cubas. É óbvia em cada uma dessas relações a ofensa a certo ideal de razão, dignidade e firmeza interior. No todo, um ambiente composto só de defeitos, de que a volubilidade de Brás - insuficiência ela também - pareceria o fruto natural. "Dessa terra e desse estrume é que nasceu esta flor. (SCHWARZ, 20I2a, p. I29-I30). 
Considerada a acomodação dessa cadeia intergeracional, disposta no meio urbano, tanto na ambiência doméstica quanto nos seus espaços de sociabilidade das frações de classe dominante, claro, no escopo da encenação literária machadiana, anota Schwarz que em lugar dos enfrentamentos envolvendo diferentes tendências sociais, à maneira da arquitetura "fabulesca" realizada nos emaranhados e sobressaltos marcantes da letra balzaquiana, em Memórias póstumas de Brás Cubas prevalece o traço anedótico incutido em frases pelas quais se comentam e captam ambiguidades. Desse modo, o fluxo narrativo da obra abre mão dos sobressaltos, mas recorre às alternâncias de pontos de vista, as quais revelam contradições de posturas que, porém, não suscitam conflitos exacerbados. A respeito delas, deflagram-se insinuações indulgentes porque, ainda que haja reprovação moral, os seus autores permanecem solidários ao que recriminam, e só em pensamento discriminam as inconsistências ou, quando muito, fazem um comentário dissimulado. A aliança tácita forjada entre os círculos de elite do Brasil imperial, portanto, faz cúmplice o "progresso" relacionado ao apelo de credo liberal à "barbárie colonial", tendo por carro-chefe a continuidade do trabalho escravo e os clientelismos destacados no costume do favor. Anulavam-se, em última instância, os extremos de uma e outra direção.

Para Schwarz, a ironia, e com ela a singularidade da prosa machadiana em sintonizar forma literária e processos sócio-históricos, está em explorar essa “cor local” que fica a meio caminho do cosmopolitismo liberal-burguês e da reposição anedótica da herança viva do patriarcado escravista. Mas ela mesma compartilha essa ambivalência, portanto sua sociogênese se situa na condição de incongruências legadas pelo encontro sociocultural intercontinental da América tropical-colonial com a Europa industrial-burguesa:

A conivência dos ricos diz respeito à conservação de relacionamentos coloniais no contexto da nação independente, em contradição com o princípio do individualismo liberal. Caso nossa paráfrase tenha cabimento, a descomunal apologia e demolição de Cotrim, empreendida por seu parente e aliado, expõe as ambivalências próprias dessa situação. No nível sintético de que a literatura tem o privilégio, cruzam-se a fruição da iniquidade, em âmbito interno ao país, e o vexame do atraso, na cena internacional. Digamos então que a ironia da prosa se constitui através da referência transatlântica sistematizada. A definição do seu território não pode ser localista, nem aliás universalista, pois a relação "anômala" entre norma burguesa e anedotas configura uma cor definidamente nacional. O movimento da escrita diz respeito, noutras palavras, a uma situação histórica precisa, de que faz parte um polo externo. (SCHWARZ, 20I2a, p. I28-I29).

O olhar lançado por Schwarz deixa, assim, pistas ao exame de como a circulação interatlântica de ideais liberais interferiu nos padrões de formação subjetiva, seja dos membros do patriarcado urbano, seja das facções que lhes eram subalternas. Ao mesmo tempo, nas entrelinhas, entendo estarem sugeridas as condições de possibilidade à demarcação de um lugar de autoria como o ocupado por Machado de Assis. Lugar de autoria este que, se ratifica o regime de assinatura individualizada, em consonância com a cultura artística de forte lastro subjetivista do Ocidente, 
o faz numa estrutura social emblematizada pela tônica posta na antecedência da família e do estamento. Seguindo as trilhas de Schwarz, daqui em diante se parte da seguinte pergunta: como o processo sócio-histórico de uma sociedade escravocrata que se moderniza modulou a formação de uma economia emocional que atravessa constitutivamente a psique de Machado de Assis, conjunção pela qual se delimitou a posição autoral machadiana, com todas as suas repercussões na montagem de um padrão intrínseco à posição de autoria literária no país?

\section{A AUTORIA MACHADIANA}

Antes de avançar na tentativa de esboçar não uma resposta mas, sim, uma interpretação para o problema enunciado no parágrafo anterior, abro um parêntese com a finalidade de delinear o que estou chamando de posição autoral.

No ensaio "O que é um autor", Michel Foucault (200I, p. 264-298) interroga o status concedido a um grupo de discursos reconhecidos como autorais numa sociedade e, no inverso, indaga as condições de designação de indivíduos a essa posição institucional-discursiva. No exame de Foucault, é importante anotar o traço de unidade e autenticidade no perfil da posição de autoria. Nesse sentido, pode-se dizer que o autor diz respeito à identidade capaz de se autogerar continuamente a partir do núcleo irradiador que se mantém igual a si mesmo. Autoria e sujeito como criador, portanto, fazem-se cúmplices ou até nomes distintos de uma mesma coisa. O filósofo sublinha, porém, o tecido complexo da operação na qual se gera a função do autor nas suas tantas facetas, mas tendo por fio comum certa economia calcada na raridade conferida à assinatura autoral. De início, Foucault observa como são recentes a atribuição de autoria e o regime de propriedade, que teriam emergido no final do século XVIII e início do XIX, período em que são redigidas as regras sobre o direito do autor, o qual contracenou com a aura transgressora da literatura, assim, o sistema literário instaurado equilibrava-se sobre a polaridade estabelecida entre reconhecimento e risco. Em momentos anteriores e mesmo simultâneos, afirma o pensador, muitos textos atualmente classificados de literários circulavam sem a obrigatoriedade do nome próprio do autor. Para ele, o que validava esses textos era o costume, o fato de perdurarem nos decursos geracionais.

Em complemento à afirmação foucaultiana, vale lembrar: no período anterior ao da juridicização da propriedade autoral, a poética estava investida do anonimato. Por exemplo, na Antiguidade Clássica, em que prevalecia a declamação dos poemas épicos pelos bardos inspirados nas musas, embora houvesse improvisações e acréscimos, essas intervenções não requeriam identificação. Algo semelhante se deu no medievo europeu, porque o conteúdo se sobrepunha aos intérpretes, estando a poética subordinada à emanação divina (BURKE, I995). A combinação de fatores como a expansão do comércio e o desenvolvimento da imprensa, além da expansão formidável da leitura e do advento da mídia livro, introduziu o problema do direito autoral e tornou a autonomia financeira do autor um ingrediente indisfarçável na localização desse personagem social (BURKE, 2003, p. I36-I58).

Quando Foucault (I996) assegura estarem, também, as sociedades definidas pelas 
específicas políticas gerais de verdade postas em vigência, as quais decorrem do efeito circular obtido pelo trançado entretendo poder e certezas ${ }^{\text {Io }}$, ele denomina essa conjunção de "regime de verdade". Os regimes de autoria podem ser entendidos como versões de regimes de verdade, quer dizer, operações discursivas cuja atuação persuasiva ocorre sobre as interdições relativas ao modo como se exerce o controle da circulação dos fluxos dos enunciados (FOUCAULT, I996, p. 8-2I). Entende-se que tais arranjos não são apenas o desvelamento persuasivo das interdições que atuam no controle social dos discursos que circulam. Sobretudo, são dispositivos espaciais em que se situam os discursos, posicionando um em relação aos outros, cujo funcionamento deixa por rastros constrangimentos, fechando as possibilidades de "dizer sobre" e "fazer algo" em relação ao que é designado objeto de conhecimento e intervenção. De um lado, ainda nos rastros do pensador francês, ratifico a proposição acerca do controle discursivo sobre a incidência continuada de falas/escritas/gestos. De outro, acrescento que os regimes de autoria compreendem o construto igualmente comunicativo que subsidia os aprendizados cognitivos e morais de pessoas envolvidas em situações de trocas públicas de sentido. E, desse modo, comparticipam do fomento de estruturas mentais de ação com as quais, a um só tempo, são formado tipos de subjetivação e agenciamentos individuais e institucionais que se orientam em relação a si mesmos, aos outros e ao mundo, no tocante à delimitação de meios e fins, objetos e limites espaçotemporais.

Se for coerente conceber que os regimes de autoria (CHARTIER, I990) não coincidem, na sua natureza fundamentalmente discursiva comunicacional, com o estatuto de um sistema social preciso, parece-me coerente especular que eles também, ao lado das ideias, circulam mundo afora como uma tecnologia discursiva de formação de subjetividades. Sob essa ótica, importa sublinhar ser o regime de autoria individualizada uma linha de força inscrita em distintas versões da modernidade, a qual é aqui entendida na sua condição bivalente de cultura histórica e civilização planetária. Resta-nos examinar a aterrissagem desse regime de autoria em iguais condições sul-americanas do Brasil pós-colonial, atendo-se aos primeiros contornos adquiridos pela esfera cultural no país em meio às peculiaridades de uma modernidade oitocentista no país.

Híbrido de estadista e poeta, José Bonifácio de Andrade e Silva é emblemático do ângulo pelo qual o problema que anima este artigo é discutido a partir de agora. Moldada em sua sensibilidade pela civilização burguesa que o penetrou na longa estada na Europa, ao voltar ao país de origem, integrando o estafe da corte de D. João VI, a postura de José Bonifácio de estrategista do Estado-nação guarda uma hesitação estrutural, bem expressiva da sua condição de classe e existência. Em momento algum, ao longo do seu Projetos para o Brasil, ele advoga a ruptura com os laços seculares entre o Brasil e Portugal, mas projeta o país como "uma terra

Io “Cada sociedade tem seu regime de verdade, sua 'política geral' de verdade, isto é, os tipos de discurso que aceita e faz funcionar como verdadeiros; os mecanismos e instâncias que permitem distinguir entre sentenças verdadeiras e falsas, os meios pelos quais cada um deles é sancionado; as técnicas e procedimentos valorizados na aquisição da verdade; o status daqueles que estão encarregados de dizer o que conta como verdadeiro” (FOUCAULT, I996, p. I3I). 
de igualdade. Igualdade no exercício dos direitos, igualdade nas pretensões legais, igualdade perante a justiça, igualdade nos impostos, igualdade no modo de adquirir, possuir e transmitir a propriedade. Não há pois interesses e privilégios de indivíduos e de classes" (SILVA, 2000, p. I89). Consta da postulação de José Bonifácio o aparente desencontro dos moldes de país livre com a arquitetura dinástico-imperial da qual era fiel súdito, como também com a estrutura social agrário-patrimonial e mercantil-escravocrata da qual era um dileto representante. Eis os dilemas que marcavam a tentativa de soldar o país mediante o ideário liberal defensor de uma sociedade de mercado, regulada pelo contrato jurídico-civil arbitrado pelo Estado centralizado, em favor da iniciativa privada e da prosperidade calcada na competência posta no mérito e no trabalho livre. Seja o próprio Roberto Schwartz (2000), ao lado de Maria Sylvia de Carvalho Franco (I999) ou, ainda, em plano mais abrangente, Florestan Fernandes (2006), todos notam que havia no Brasil fatores heterônomos ao pleito de relações capitalistas fundadas na remuneração autoexpansiva do capital dinamizadas pela extorsão de trabalho não pago de produtores liberados, despossuídos de meios de sobrevivência, a não ser o próprio esforço e teor subjetivo, diante dos concentradores de meios de produção. Antes, o ideário de um mercado livre de trabalho estava de antemão obstado pela instituição da escravidão.

O foco das ambiguidades e ambivalências, tornando senhores patriarcais ou traficantes de pessoas em liberais, dizia respeito àquele elo umbilical estabelecido que sancionava o movimento no qual do ventre de uma estrutura patriarcal-agrária e escravocrata ganhava luz uma titubeante sociedade urbano-manufatureira, principalmente na metade final do século XIX. Entretanto, as convulsões da metade inicial do mesmo século - em Recife, a Confederação do Equador, a expulsão de Pedro I, a Revolução Praieira, a Revolta dos Malês, a Sabinada, a Cabanagem, a Balaiada, o movimento liberal em Minas Gerais e São Paulo e a Guerra Farroupilha - atestam os percalços do parto da nova estrutura social. É oportuno registrar estarem, nessa base social emergente, os elementos subjetivos e institucionais responsáveis por potencializar as repercussões do saber institucionalizado já muito comprometido, na época, com a formação daquela "literatura da independência", de acordo com Antonio Candido (I997), a qual combinaria nativismo e patriotismo. À medida que interessa sublinhar as linhas de forças sócio-históricas que, no desenho da esfera cultural no país, delimitam um lugar de autoria literária, o que se impõe como objeto de exame é a conversão das ambiguidades acima sinalizadas na mediação da inautenticidade que, ao mesmo tempo, fomenta a forma literária machadiana e a posição de autoria em que Machado de Assis se subjetivou como autor.

Em um primeiro momento, faz-se pertinente chamar a atenção ao processo de centripetação estatal das relações sociais que ensejou uma coordenação institucional-política, nucleada pela corte composta em torno do imperador e das relações peculiares estabelecidas com as oligarquias regionais, seja mediante os acertos parlamentares, seja no recrutamento para cargos no interior do aparato administrativo-burocrático estendido com a autonomia política desde I822. E, também, esteve conectada à delimitação da esfera cultural nos limites possíveis de um espaço público, situado no âmbito literário e jornalístico. Se parece ser esse um problema estrutural à institucionalização desse âmbito da experiência social, na formação social brasileira 
a situação tem cores muito próprias no século XIX, principalmente pela interferência da instituição escravocrata em consórcio com o modelo agrário-exportador, ambos articulando os estamentos senhoriais ao mercado mundial e a burguesias europeias. De antemão, vimos, tal situação descartava a igualdade entre os homens, em termos de cidadania, e fazia da ideologia liberal-democrática ideia sem base no país quanto ao seu postulado universalista, igualitário e emancipacionista. Por outro lado, enquanto responsável pela unificação jurídico-institucional do país, tendo por horizonte ideológico o liberalismo estamental, o Estado monárquico absorveu a esfera pública e permaneceu como agente homogeneizador e também da modernização do país. As transformações que se sucederam durante o mesmo século reformulam a paisagem sócio-humana brasileira, notadamente em sua capital na época; o Rio de Janeiro é a parte mais sensível dos deslocamentos visíveis com a formação de um capital comercial e posteriormente industrial. As disparidades advindas da economia agroexportadora e da estrutura social do Império se agudizam com o advento do modelo societário vertical-competitivo e com o postulado republicano de uma nação de cidadãos universalmente equalizados. Nesse contexto, a ideia de povo-nação se expande no imaginário político e cultural. Os primeiros passos na direção da entidade povo-nacional estavam na contrapartida da sociedade inclusiva em formação e, com ela, a exigência de uma esfera regularizada pela não mercantilização e voltada à resolução dos conflitos. À maneira das soluções europeias, o policiamento dos indivíduos torna-se o dado fundador do estado de direito, justamente sob a alegação de manter as condições de sobrevivência do indivíduo autodeterminado. Porém, parcelas enormes da população rural e urbana nem sequer desfrutavam do direito à educação escolar, não pertenciam ao mercado formal das relações de produção, e prevalecia a natureza localista-oligárquica do poder governista. Desse modo, a tessitura de uma esfera pública nos marcos da sociabilidade burguês-capitalista é marcada pela seletividade inerente ao processo sócio-histórico modernizador no país, pois o primado de uma ampla dialogia entre cidadãos iguais é desde logo frustrada. No Brasil imperial, tal espaço de visibilidade e ilustração incorpora a ordenação como âmbito capacitado a conferir visibilidade a imagens privadas que detenham lugar premente no interior da arquitetura estatal, aproximando a mercantilização dos bens culturais às vicissitudes dos esquemas burocráticos do poder político.

Sintomática a respeito é a atividade jornalística durante o Império. Em seu estudo sobre a institucionalização do jornalismo no Brasil, Lavina Madeira Ribeiro (2004) chama a atenção para a tônica prioritariamente política desse ofício na época. Por corresponder a um dos poucos canais de mobilidade em um cenário demasiadamente restrito, o exercício jornalístico não compreendia uma atividade exclusiva e estava orientado para contribuir com o ingresso na arena parlamentar daqueles não inscritos na área jurídica, setor no qual se recrutavam, em sua maioria, os membros da elite política. A ênfase parcialista na defesa das respectivas intenções como motivação para o jornalismo político, a seu ver, favoreceu o desenvolvimento do estilo opinativo, mas orientado para reiterar perspectivas defendidas pelos pares do próprio jornalista. Diante das insuficiências organizacionais e profissionais, mesmo das propriedades dos mecanismos expressivos, o âmbito jornalístico se definia como uma prática publicista interpelada pelos distintos ramos da esfera 
cultural - científico e artístico. Eram acionados recursos vários na elaboração de um meio de conhecimento comum capaz de ativar o diálogo com um público leigo e culto, no combate aos ingredientes da tradição em nome do incremento da racionalização das imagens de mundo. Algo assim teria resultado, de início, em certa indiferenciação (RIBEIRO, 2004, p. I65-I66). Para a autora, no decorrer do século XIX, tal convergência declinou diante da crescente delimitação de zonas especializadas em que se foram abrigar os distintos discursos com seus objetos e racionalidades próprios. Em especial, a atmosfera acadêmica propícia à ciência se aninhou nas escolas, faculdades, institutos de ensino e pesquisa, museus, arquivos e bibliotecas.

No entanto, de acordo com o próprio argumento da autora, manteve-se o vínculo entre literatura e jornalismo, em certa medida atualizando a tradição educacional herdada das escolas jesuítas (RIBEIRO, 2004, p. I67). Logo, em um primeiro entendimento, parece ter se repetido no Brasil a tendência de diferenciação entre ciência e literatura observada na Europa. Sabemos, por meio de Wolf Lepenies (I996), o quanto se deram de maneira tensa as relações entre elites intelectuais científicas e literárias europeias na passagem do século XIX para o XX, sob a esteira dos respectivos movimentos de autonomia dos campos artístico-literário e científico, definindo igualmente modos específicos de produção simbólica. Ao acompanhar os contextos francês, inglês e alemão, nota o autor como, em se tratando da sociologia, essa tensão imprimiu caracteres bem peculiares, afinal essa disciplina compareceu na figura de uma "terceira cultura", interseccionando propriedades que seriam particulares a cada um de ambos os domínios discursivos. Porém, em se tratando do Brasil, as mesmas informações arroladas por Lavina Ribeiro assinalam aspectos merecedores de maior atenção, tendo em vista compreender os impasses à potencialização do campo científico no país e, também, a importância gozada pelo discurso literário. A autora ressalta a atualização da tradição escolar introduzida e disseminada pelos jesuítas de acordo com o projeto civilizatório da igreja católica para o Novo Mundo. Em aliança com o poder secular da coroa portuguesa, a Igreja assegurou o lugar institucional da transmissão do conhecimento; lugar renovado com a autonomia política brasileira, em I822, e mantido no curso do Império. Observa Fernando Azevedo (I994) que, na continuidade institucional eclesiástica, adquiriu vigor a tradição fundada nos imperativos do humanismo da Contrarreforma, cujos moldes enfatizam a competência retórica, mas se calcam em sistemas preordenados, logo indiferentes à dúvida e ao experimentalismo. Um e outro traço adaptaram-se bem à estrutura socioeconômica agroescravocrata e mercantil excludente de atividades manufatureiras, mas também hostil à cientificidade, se esta última for entendida como espírito aberto à pesquisa do novo.

Argumenta ainda o autor que a chegada da família real portuguesa, liderada por D. João VI, em I808, lançou sementes, que, no decorrer do século XIX, paulatinamente contribuíram para alterar as condições desfavoráveis à ciência no país. Sem dúvida repercutiram no plano da produção e transmissão do conhecimento, assegura Azevedo, o estabelecimento dos cursos médico-cirúrgicos na Bahia e no Rio de Janeiro, a fundação da Imprensa Régia, a inauguração da Biblioteca Nacional, das academias militares, do Real Horto e do Museu Real. No entanto, ele conclui, no instante da independência o aperfeiçoamento das elites visou tão somente equipá-las 
para responder à convocação de Pedro I "a assumir a responsabilidade da imensa tarefa que tiveram de tomar sobre os ombros, de “construtores de nação”" (AZEVEDO, I994, p. 32). A seu ver, a bandeira da construção e defesa nacional estendeu-se no decorrer da era imperial, em meio às lutas pela conquista e manutenção da unidade nacional, e as prerrogativas internas às disputas pela rotativa entre os partidos no parlamento favoreceram a figura do tribuno motivado a "amaneirar" o estilo teatral da improvisação e do jogo retórico. Em contrapartida, faltando uma efetiva política de Estado de apoio ao desenvolvimento científico, afirma o autor, vigorou a atitude de mecenas, sintetizada no próprio imperador Pedro II, e, também, a obstinação isolada de homens movidos pelo ideário da ciência.

Por extrapolar os objetivos deste texto, deixo de lado a questão da ciência no país. Interessa indicar que, tanto em Lavina Ribeiro quanto em Fernando Azevedo, a transformação da tradição escolar jesuítica na cultura bacharelesca aponta à ênfase utilitarista do saber, para a qual o conhecimento constitui espécie de insígnia e dispositivo burocrático na preservação da ordem. Ambos igualmente desvelam o entrosamento nos quadros do Estado Imperial da esfera pública dinamizada por agentes publicistas embebidos do espírito literário-ilustrado, coparticipando da unificação institucional e cultural do jovem Estado nacional. Nesse sentido, é possível concluir o quanto tal encadeamento artístico-intelectual fomentou a esfera cultural como um fórum de modulação dos sentidos cotidianamente vividos e, assim, contribuiu com o projeto de inscrição do país no leito da civilização ocidental.

Anota Roberto Ventura (I99I), por sua vez, o quanto, no decorrer de toda a metade inicial do mesmo século XIX, os esforços de uma "ilustração tropical" se definiram justamente pelo empenho de viabilizar uma civilização no Estado independente do Brasil. E algo assim se defrontara com tensões internas - raciais, sociais, falta de unidade entre as diversas regiões do país e, principalmente, ausência de história "autêntica”, quer dizer, desvinculada da metrópole portuguesa. Temos aqui indícios sobre os caminhos possíveis à emergência do debate em torno da inautenticidade da cultura brasileira, acaso se pergunte: com quais materiais operaram os "ilustrados tropicais" no cumprimento da sua missão civilizatória? Literatura e historiografia se tornaram decisivas. A historiografia devido à busca da particularidade na continuidade temporal da existência do país. Já a literatura em razão do tema da língua como fator de singularidade e unidade nacional. Não resta dúvida que, a respeito da iniciativa de nacionalizar os sentimentos mediante a literatura, destaca-se o nome de Gonçalves Dias, com a publicação dos seus Suspiros poéticos e saudades, em I836. Mas, se os ilustrados ciclos literários da Arcádia, no século XVIII, foram inspiradores, as matrizes dessa postura podem ser identificadas, nas primeiras décadas do século XIX, com a transferência da família real para o Brasil (CANDIDO, I987, p. II-4I; BOSI, I980). O relativo progresso técnico e institucional então conhecido na sociedade teve por contrapartida o impulso de fazer do país a motivação para a prática poético-literária (CANDIDO, 2000, p. 26) e erguer desde aí um projeto literário nacional de corte nativista, dotando o país de uma civilização singular, lastreada por valores, mitos e ícones originais (FRANÇA, I998). Repercutiram a favor as impressões de viagens reunidas pelo francês Ferdinand Denis (I980), no livro Resumo da história da literatura brasileira, editado em I826. Na obra, o autor exulta que os poetas 
brasileiros se inspirem nas paisagens do país. Escudado no método do romantismo alemão sobre a influência do clima de determinada região na imaginação artística de um povo, Denis traça a evolução da literatura brasileira a partir do encontro da cultura europeia com a exuberância natural da América, posteriormente acrescentando o contato com nativos e africanos (CUNHA, 200I, p. IX-LIX).

Por ter desempenhado papel decisivo tanto na promoção de uma esfera pública restrita quanto no efetivar de um imaginário nacionalista, aos moldes liberais de uma sociedade autônoma de cidadãos livres, o âmbito literário resulta heurístico à escuta da relação estabelecida entre mediação da inautenticidade e posição de autoria. O nativismo de José de Alencar é elucidativo a respeito, afinal, juntos, nele se equilibram o projeto de uma autenticidade brasileira e a participação nos efeitos da "cruzada" ocidentalizante que derivou, igualmente, do empenho de acomodar o Brasil na órbita da "civilização", a partir da chegada da família real portuguesa (FRANÇA, I980). De acordo com Alfredo Bosi (I992, p. I76-I93), embora estivesse influenciada pelas prerrogativas do romantismo europeu de retorno ao passado, ao Antigo Regime, a prosa alencariana esteve pautada em uma tensa dualidade estrutural. Porque é verdade que o processo de independência fazia inflar as questões da identidade, mas da perspectiva do emergir do novo; porém também é factível que pesavam os vínculos com Portugal, com a Colônia, enfim, com a continuidade no presente, representada pelo Império. Nesse sentido, a figura do índio atravessando a obra de Alencar secreta uma ambiguidade, já de antemão deslocada da tônica na rebeldia. Afinal, sob a égide da aura jesuítica, o nativo é a expressão medieval do "bom selvagem", ao mesmo tempo que está à mercê da nomeação conferida pelo senhor, comparecendo como descendência do colonizador português. Assim, ainda nos rastros de Bosi (I992, p. I76-I8I), o romance nacional - em O Guarani e Iracema - vem à luz sob o signo do sacrifício consentido do índio como que cumprindo a missão civilizatória do branco europeu. Não é difícil concluir a situação bifronte instaurada: na narrativa mítico-épica que simbolicamente a aciona, a formação nacional toma o nativismo como fator crucial, contudo, o nativo só é entronado à medida que cumpre a sanha de se dissolver no caldeamento conduzido pelo adventício, possuidor da autoridade para decidir o preparo étnico-histórico nacional da síntese cultural brasileira. Desse ponto de vista, o modelo medievalista é traduzido para os trópicos, guardando o esquema estamental e hierárquico, ou seja, senhor e servo - colonizador e índio conquistado/pacificado. $\mathrm{O}$ termo de referência, a terra, fora crescentemente idilizado, se inscrevendo como o país - o torrão natal, o continente. A operação ideológica nesse aspecto é notável. A arquitetura do discurso nacional recolhe o passado medieval - o signo castelo, em $O$ Guarani, por exemplo. No entanto, isso se faz no mesmo andamento em que a figura do índio é conduzida aos umbrais do tempo originário, ao paraíso tal qual descreve o mito adâmico, ou seja, o nativo personifica a pureza, logo, é coerente que nele se decalque a civilização.

A obra de Alencar deixa ver como a "cruzada civilizatória" de um projeto em que se compromete a estética das letras aos desígnios políticos da construção da nação sobressai como tema e esquema de composição literária. Parece ser verdade também que a mesma cruzada, cujo denodo nacionalista sublinha a obediência da cultura às coordenadas estatais, fora imprescindível para contornar os limites da posição 
de autoria, ou melhor, do lugar institucional do "gênio literário", a partir do qual a agência subjetivada estaria incumbida de potencializar uma identidade nacional por meio da atuação pedagógica da atividade literária. Poder-se-ia concluir que a resposta positiva ao chamado dessa militância estético-política nacionalista serviria de parâmetro à inferência da verdadeira vocação para as belas-letras.

Informada pela elucidação bourdiana (BOURDIEU, I996, p. 63-3I8) do problema a respeito da produção dos criadores, observa Andréa Borges Leão (2009, p. 30I-302) que, no sistema cultural definido pela especialização técnica e diferenciação funcional inerente à produção, circulação de bens simbólicos descritos como obras de arte, embora estejam articulados, opõem-se valores relativos aos "regimes de singularidade" daqueles referentes aos "regimes de comunidade" (HEINICH, 2000). Assim, prossegue a autora, como criação, a literatura reitera as tensões entre a "afirmação dos valores centrados no indivíduo, a criatividade e o poder de inovação dos escritores, e as regras comuns que configuram e orientam as relações no mundo literário” (LEÃO, 2009, p. 302). A dinâmica própria aos círculos literários teria por anima "dependências recíprocas entre os comportamentos individuais e a organização de instituições com seus poderes de consagração e reconhecimento, a exemplo das academias de letras, dos salões, do mercado editorial, etc." (LEÃO, 2009, p. 302). Logo, deixa ver Borges Leão, a iniciação e a afirmação autoral estão atravessadas na sua constituição pela participação em interações em que ocorrem lutas de posicionamentos e por reconhecimentos entre os pares. Com isso, conclui-se sobre a cumplicidade da tessitura da eficácia simbólica das obras e a consagração dos autores com a formação das disposições elementares e duráveis dos seus produtores e receptores, "desde os escritores que as concebem na solidão do trabalho individual e na intimidade de suas consciências, passando pelos profissionais da edição e comércio de livros, até as disposições e habitus de leitores especializados ou anônimos" (LEÃO, 2009, p. 302).

Com respaldo nessa lente da sociologia da produção dos autores, volto ao tema do delineamento do lugar de autoria literária no Brasil. Argumenta Martins (2002) que, na juventude, Machado de Assis não hesitou em tomar a palavra em defesa de uma literatura com explícitos compromissos inadiáveis com a construção da pátria-nação. Merecia aplausos, para o então jovem literato, a condução do ofício literário que dispusesse seu criador à tarefa pedagógica de civilizar os potenciais leitores, convertendo-os em integrantes do povo nacional. A certa altura da análise a que submete o ensaio machadiano $O$ passado, o presente e o futuro da literatura, Martins (2002,) observa que o autor incorre em semelhante hábito comum aos intelectuais brasileiros do Império: apropriavam-se de obras filiadas a vertentes teóricas e mesmo de perspectivas político-ideológicas contraditórias entre si. O traço eclético dispunha-se na participação desses intelectuais da circulação transatlântica de ideias. Gerava-se, desse modo, a incongruência entre os propósitos de soerguer um pensamento nacional e as bases intelectuais sobre as quais este último deveria se pôr de pé. Volta-se, assim, ao tópico da inautenticidade da formação e dinâmica da cultura brasileira. Agora, no entanto, está em pauta a posição em que se subjetivavam falas como "autoria brasileira", naquele momento. O traço eclético assinalado parece corresponder, a um só tempo, a uma propriedade cognitiva e estilística embasada numa moralidade tendo por fundamento de bem a nação civilizada. Ora, no movimento em que esse traço definia uma propriedade 
intrínseca ao controle das falas e dos discursos que circulavam na sociedade, também funcionava como um saber tácito com implicações nos aprendizados que repercutiam na socialização dos corpos (fomentando disposições e hábitos mentais), posteriormente recrutados como partes dos quadros intelectuais do Império.

No ensaio "Duas notas sobre Machado de Assis" - também incluído em Que horas são? -, Schwarz (I997, p. I65-I78) resgata da biografia do escritor a origem modesta e racializada pela mestiçagem, a qual o categorizou como "mulato", mas numa família comprometida por laços de favor ao núcleo estamental abastado. A convivência com pais alfabetizados teria favorecido a sua entrada no mundo das letras; primeiro, exerceu o ofício de tipógrafo; depois, de redator. Mobilidade social posteriormente assegurada ao se fixar como parte do quadro burocrático do Império brasileiro. Situação de estabilidade socioeconômica adequada à sua consolidação como parte de um casal burguês, além de básica para levar adiante a atividade literária. Os louros da fama foram colhidos em vida. Já a celebração como herói cultural da nação deu-se com a sua morte. Não é demais lembrar que, se esse encadeamento biográfico parece deslocar Machado de Assis da posição do dependente atravessado pelo sistema social do favor àquela do autor festejado, pelo que se viu, ele emerge no espaço social de possíveis da literatura brasileira ao ser formado no caudal daquela socialização intelectual ambígua, por estar comprometida com a cruzada civilizatória ocidentalizante, em nome da construção da nação.

A celebração como romancista se fez nos desdobramentos da maneira como, nele, os saberes decorrentes dessa socialização o capacitaram a disputar posições nesse espaço literário nacional (ainda que fortemente concentrado no Rio de Janeiro) em formação. Portanto, a aura que lastreia a raridade do nome próprio de Machado de Assis como autor veio e se fixou no compasso da maneira como a formação do campo literário no país definiu chancelas de exposição e controle das falas, centrando na posição do criador individualizado a agência autorizada a transpor em letras os componentes, sejam formativos, sejam complementares, da identidade nacional. Ora, a sua maturidade como escritor é constatada na medida em que, para tematizar a inautenticidade dos segmentos abastados e dos dependentes, soube tirar partido da mesma ambiguidade entre o cosmopolitismo liberal e o localismo colonial para forjar uma forma artística e uma linguagem singular. Já Antonio Candido (I997) destacou o acolhimento por parte de Machado de Assis de todo o percurso literário brasileiro que o antecedeu, sobretudo porque se mostrou capaz de "fecundar" esse legado. Fecundou-o na medida pela qual teria colocado as letras nacionais cada vez mais em comunicação com os insumos técnicos e conteudísticos da produção literária universal. Mas o teria feito em consonância à "causalidade interna" oriunda do trajeto formativo desse espaço literário em que ascendeu como herdeiro. O saldo de tal "acumulação literária" seria a "superação" da dependência por parte da literatura brasileira (SCHWARZ, 20I2a, p. 22I-243; ARANTES, I997, p .29-32). Fundador da Academia Brasileira de Letras, com Machado de Assis a autoria brasileira atingira um grau acentuado de diferenciação sociofuncional como posição em que se subjetivam enunciados, conquistando autonomia relativa para decidir o que é ou não literário, sobretudo, reconhecer quem são os(as) herdeiros(as) continuadores(as) da cidade das letras. 


\section{SOBRE O AUTOR}

EDSON FARIAS é pesquisador do CNPq, professor do Departamento de Sociologia da Universidade de Brasília (UnB) e do Programa de Pós-Graduação em Memória: Sociedade e Linguagem da Universidade Estadual do Sudoeste da Bahia (UESB), líder do grupo de pesquisa Cultura, Memória e Desenvolvimento (CMD/UnB) e editor da revista Arquivos do CMD.

E-mail: nilosed@gmail.com

https://orcid.org/0000-0002-9406-3269

\section{REFERÊNCIAS}

ABREU, Márcia (Ed.). Romances em movimento: a circulação transatlântica dos impressos (I789-I9I4). Campinas: Unicamp, 2016.

ADORNO, Theodor W. Teoria estética. Lisboa: Edições 70, I992.

ALENCASTRO, Luiz Felipe de. O trato dos viventes: formação do Brasil no Atlântico Sul. São Paulo: Companhia das Letras, 2000.

ARANTES, Paulo E. Providências de um crítico literário na periferia do capitalismo. In: ARANTES, Otília B. F.; ARANTES, Paulo E. Sentido da formação: três estudos sobre Antonio Candido, Gilda de Mello e Souza e Lúcio Costa. Rio de Janeiro: Paz e Terra, I997.

ARAÚJO, Ricardo Benzaquen de. Guerra e paz: Casa-grande e`senzala e a obra de Gilberto Freyre nos anos 30. Rio de Janeiro: Editora 34, I994.

AUERBACH, Erich. Mimesis: a representação da realidade na literatura ocidental. São Paulo: Perspectiva, I97I.

AZEVEDO, Fernando. As ciências no Brasil. Rio de Janeiro: Editora da UFRJ, I994. 2 v..

BADIOU, Alain. Panorama de la filosofía francesa contemporánea. Nómadas (Col), 2005, 23, p. I75-I83.

BATESON, Gregory. Naven. São Paulo: Edusp, 2008.

BIANCHI, Alvaro. O marxismo fora do lugar. Política ef Sociedade, v. 9, 20Io, p. I77-204.

BOSI, Alfredo. História concisa da literatura brasileira. São Paulo: Cultrix, I980.

. Dialética da colonização. Prefácio de Graça Capinha. São Paulo: Companhia das Letras, I992.

BOURDIEU, Pierre. As regras da arte: gênese e estrutura do campo literário. São Paulo: Companhia das Letras, I996.

BURKE, Sean. Reconstructing the author. In: . Authorship: from Plato to the postmodern. Edinburgh: Edinburgh University Press, I995. . Uma história social do conhecimento: de Gutenberg a Diderot. Rio de Janeiro: Zahar, 2003.

CANDIDO, Antonio. Dialética da malandragem. Revista do Instituto de Estudos Brasileiros, n. 8, I970, p. 67-89. . Formação da literatura brasileira. 2 v. Belo Horizonte/Rio de Janeiro: Itatiaia, I987.

CANDIDO, Antonio. Literatura e sociedade. São Paulo: T. A. Queiroz - Publifolha, 200o. (Grandes Nomes do Pensamento Brasileiro).

CARDOSO, Fernando H. As ideias e seu lugar. Petrópolis: Vozes, I995. 
CHARTIER, Roger. Por uma sociologia histórica das práticas culturais. In: . A história cultural, entre práticas e representações. Rio de Janeiro: Difel, I990, p. I3-28.

COUTINHO, Afrânio (Org.) Machado de Assis. Obra completa. V. III. Rio de Janeiro: Nova Aguilar, I985. CUNHA, Cilaine Alves. Introdução. In: DIAS, Gonçalves. Cantos. São Paulo: Martins Fontes, $200 I$.

DAMATTA, Roberto. Carnavais, malandros e heróis: para uma sociologia do dilema brasileiro. Rio de Janeiro: Rocco, I997.

DENIS, Ferdinand. Brasil. Belo Horizonte: Itatiaia; São Paulo: Edusp, I980.

ELIAS, Norbert. A sociedade dos indivíduos. Rio de Janeiro: Jorge Zahar, I994.

EWALD A. P. Fenomenologia e existencialismo: articulando nexos, costurando sentidos. Estudos e Pesquisas em Psicologia, v. 8, n. 2, 2008, p.I49-I65.

FARIAS, Edson. Hoje é festa na metrópole: considerações sobre expressões lúdico-estéticas no carnaval carioca, In: RUBIM, Linda; MIRANDA, Nadja (Org.). Estudos da festa. Salvador: Edufba, $20 I 2$.

FERNANDES, Florestan. A revolução burguesa no Brasil: ensaio de interpretação sociológica. São Paulo: Livros, 2006.

FOUCAULT, Michel. Ordem do discurso. São Paulo: Edições Loyola, I996. . O que é um autor?. In: Estética: literatura e pintura, música e cinema. Michel Foucault: Manoel Barros da Motta (org. e seleção de textos). Rio de Janeiro: Forense Universitária, 2001.

. A hermenêutica do sujeito. São Paulo: Martins Fontes, 2004.

FRANCO, Maria S. C. Homens livres na ordem escravocrata. São Paulo: Unesp, I997.

FREYRE, Gilberto. Casa-grande er senzala: formação da família brasileira sob o regime da economia patriarcal. Rio de Janeiro, José Olympio: I987.

. Sobrados e mucambos: decadência do patriarcado rural e desenvolvimento urbano. Rio de Janeiro: Record, 2000.

GONÇALVES JR., Arlindo F. A noção de inautenticidade em Heidegger e Sartre. Reflexão, Campinas, v. 30, n. 87, jan/jun, 2005, p. 3I-4I.

HEINICH, Nathalie. Être écrivain: création et identité. Paris: La Découverte, 2000.

LEÃO, Andréa B. Como fazer uma sociologia da singularidade? Autoria e campo literário. Estudos de Sociologia, Araraquara, v. I4, n. 27, 2009, p. 30I-3I6.

LEPENIES, Wolf. As três culturas. São Paulo: Edusp, I996.

LUKÁCS, György. A teoria do romance: ensaio histórico-filosófico sobre as formas da grande épica. São Paulo: Editora 34, 2000.

. Narrar ou descreve. In: . Marxismo e teoria da literatura. Apresentação e tradução: Carlos Nelson Coutinho. São Paulo: Expressão Popular, 20Io.

MAIA, João M. E. Ideias, intelectuais, textos e contextos: novamente a sociologia da Cultura... BIB - Revista Brasileira de Informação Bibliográfica em Ciências Sociais, Anpocs, 2005, p. 53-72.

MARTINS, Ricardo André Ferreira. Machado de Assis e a literatura brasileira do Oitocentos: um projeto de literatura nacional. Revista de Hisória Regional, v. 7, n. 2, Inverno, 2002, p. 9-32.

PALTI, E. J. El problema de "las ideas fuera de lugar" revisitado. Más allá de la "historia de ideas”. Terra, 6I, 92, I992.

RIBEIRO, Lavina Madeira. Imprensa e espaço público: a institucionalização do jornalismo no Brasil (I808I964). Rio de Janeiro: E-Papers, 2004.

RICUPERO, Bernardo. Da formação à forma. Ainda as “ideias fora do lugar". Lua Nova, n. 73, 2008, p. 59-69. RODRIGUES, Lidiane Soares. A produção social do marxismo universitário em São Paulo: mestres, discípulos e um seminário (I958-I978). Tese (Doutorado em História). Programa de Pós-Graduação em História Social, Universidade de São Paulo, 20 II. 
SCHWARZ, Roberto. Que horas são?: ensaios. São Paulo: Companhia das Letras, I987.

SCHWARZ, Roberto. Ao vencedor as batatas: forma literária e processo social nos inícios do romance brasileiro. São Paulo: Editora 34, 2000.

SCHWARZ, Roberto. Um mestre na periferia do capitalismo. São Paulo: Editora 34/Duas Cidades, 20I2a. . Por que "ideias fora do lugar"?. In: . Martinha versus Lucrécia: ensaios e entrevistas. São Paulo: Companhia da Letras, 20I2b, p. I65-I72. . Aos olhos de um velho amigo. In: . Martinha versus Lucrécia: ensaios e entrevistas. São Paulo: Companhia da Letras, 20I2c, p. 207-2I4.

SILVA, José Bonifácio A. Projetos para o Brasil. Textos reunidos e comentados por Miriam Dolhnikoff. São Paulo: Companhia das Letras; Publifolha, 2000. (Grandes Nomes do Pensamento Brasileiro).

VENTURA, Roberto. Estilo tropical. São Paulo: Companhia das Letras, I99I.

WAIZBORT, Leopoldo. Erich Auerbach sociólogo. Tempo social, v. I6, n. I, 2004, p. 6I-9I. . A passagem do três ao um: crítica literária, sociologia e filologia. São Paulo: Cosac Naify, 2007.

WALLERSTEIN, Immanuel. El moderno sistema mundial III (La segunda era de gran expansión de la economía-mundo capitalista, I730-I850). México (D.F.): XXI, 2011. 